\title{
Measuring the net profit of laboratory services: A case study in Iran
}

\author{
Ali Mouseli ${ }^{1}$, Mohsen Barouni ${ }^{2}$, Mohammadreza Amiresmaili ${ }^{3}$, Siamak Mirab Samiee ${ }^{4}$, Leila Vali*5 \\ Received: 24 Feb 2017 \\ Published: 12 Feb 2018
}

\begin{abstract}
Background: Clinical laboratories need to manage resources properly and scientifically to survive in today's highly competitive environment. In this context, scientific-economic principles should be considered to determine the profitability or loss of laboratories. Thus, in this study, the net profit of laboratory services was measured based on scientific-economic principles.

Methods: This was an applied research with descriptive-retrospective approach. A laboratory was selected from 61 laboratories of Kerman, Iran, which performed the highest number of tests among the laboratories of this city. In addition, due to easy access, it was the most visited laboratory by patients. The present study had 2 main phases: (1) measuring the price of services and (2) calculating the net profit of the studied laboratory. Data analysis was performed using activity- based costing (ABC) as an econometric model and Excel software.
\end{abstract}

Results: The highest charges were related to direct costs (78.28\%); consumable goods (47.26\%) and professional and logistic human resources $(46.31 \%)$ had the highest share of these costs. In the test groups, the most expensive tests belonged to the hormones $(23.03 \%)$ and clinical chemistry (20.84\%). Total cost, revenue, and the net profit of the studied laboratory were 641 645, 1390942 , and 749297 USD, respectively. After doing sensitivity analysis (50\% increase in the frequency of tests), the following values were obtained: 987 071, 2086 413, and 1099 342, respectively.

Conclusion: Some test groups in the studied laboratory were not profitable, and this was due to the high cost of these tests and illogical tariffs. One way to overcome this problem is to increase the frequency of laboratory tests.

Keywords: Cost price, Direct and indirect costs, Net profit, Clinical laboratories, Tariffs

Copyright $\subseteq$ Iran University of Medical Sciences

Cite this article as: Mouseli A, Barouni M, Amiresmaili M, Mirab Samiee S, Vali L. Measuring the net profit of laboratory services: A case study in Iran. Med J Islam Repub Iran. 2018(12 Feb);32:12. https://doi.org/10.14196/mjiri.32.12

\section{Introduction}

Clinical laboratories are vital departments that assist health care providers in diagnosis, treatment, and prevention of diseases, especially in modern medicine (1-3) because two thirds of important medical decisions are made through the laboratory tests results $(4,5)$. Nowadays, the number of laboratory tests and their requests have increased. The reasons are development of new laboratory

Corresponding author: Dr Leila Vali,vali1386@gmail.com

1. Social Determinants in Health Promotion Research Center, Hormozgan Health Institute, Hormozgan University of Medical Sciences, Bandar Abbas, Iran, \& Department of Health Management, Policy and Economics, Kerman University of Medical Sciences, Kerman, Iran.

2. Modeling in Health Research Center, Institute for Futures Studies in Health, Kerman University of Medical Sciences, Kerman, Iran.

3. Medical Informatics Research Center, Institute for Futures Studies in Health, Kerman University of Medical Sciences, Kerman, Iran.

4. Health Reference Laboratory Research Center, Ministry of Health and Medical Education, Iran.

5. Environmental Health Engineering Research Center, Kerman University of Medical Sciences, Kerman, Iran. equipment and the opportunity provided to physicians in making an appropriate diagnosis $(3,6)$. These factors have led to an increase in laboratory costs (1).

About $10 \%$ of total health care costs are spent on laboratory services (1). Nowadays, due to regulations set for the health systems, many countries face financial restrictions $(7,8)$, and thus, it is essential that funds be used efficiently

$\uparrow$ What is "already known" in this topic:

Laboratories face scarcity of resources due to cost of their services. Direct and indirect costs of laboratories and their profitability should be managed using scientific methods. Activitybased costing is a good method to measure cost areas and profit and loss rates.

\section{$\rightarrow$ What this article adds:}

To avoid bankruptcy, laboratories tend to conduct more profitable tests, which can decrease the quality of services. Increasing the capacity to perform more tests can be one of the solutions for profitability because it decreases costs. Increasing this capacity may result in the integration of laboratories and formation of mega-labs, which can be a suitable solution for providing high quality, accessible, and profitable laboratory services. 
to manage clinical laboratories $(9,10)$. Also, the managers of these sectors should improve productivity and control the costs of the health system scientifically to maintain their position in today's competitive world $(1,3)$. Controlling costs requires information about resources and costs by different laboratory units. This can be obtained through the use of scientific methods of costing and its analysis $(7,11)$.

Costs that are directly or indirectly spent on laboratory services can be identified using scientific methods. Costly domains, and on the other hand, the benefits of these domains can also be determined $(12,13)$. This could reflect the overall profitability of the laboratory and that of each test (14). Net profit is the calculation of the income after deducting costs (15). Jafari Sirizi et al., by calculating the profitability of laboratory and radiology departments in public and private sectors in Kerman (Iran), found that costs of selected tests in laboratories were higher than the tariffs. This situation was less severe in the private sector (11). Buljanovic et al. simulated an economic model to improve the performance of laboratories. They created a model based on SWOT analysis. In reality, laboratories' profit increases with the use of detected strengths and opportunities. Conversely, with the occurrence of threats, the amount of profit will reduce (16).

Kerman is the most developed and important city in the southeast of Iran, with a population of 740000 and an area of about 45401 square kilometers. There are 61 laboratories in this city, which imposed over 12535000 USD to the health system in 2015. According to Mouseli's study, there were 16 laboratories that performed less than 60000 tests a year (17). Thus, given the fixed and variable costs, these laboratories are not economic in scale. Thus, calculating their profits and losses using a scientific method is necessary for the survival in the competitive market of laboratories. Therefore, the present study was conducted to examine the cost and net profit of a clinical laboratory in Kerman, Iran, to provide a guidance for better management of clinical laboratories.

\section{Methods}

This was an applied research with descriptive-retrospective approach. One laboratory was selected from 61 laboratories in Kerman, Iran. Because the present study aimed at calculating the gained profit from laboratory tests, we selected a laboratory with the largest number of tests, based on the laboratories tariff book. The selected laboratory was able to perform 188 tests of 629 tests in the tariff book, which was the highest number of tests performed among the laboratories in Kerman. Also, due to easy access, it was the most visited laboratory by patients.

This study had 2 main phases: (1) measuring the cost of services and (2) calculating the net profit of the studied laboratory. In the first phase, the cost was calculated using activity- based costing (ABC) and by following formula: Total $=\Sigma$ personnel cost + consumable goods cost + depreciation cost + building opportunity cost + energy cost + other costs

Fixed parameters for calculating the above formula were as follow:

- Laboratory area (153 square meters)

- Number of personnel and monthly salary per person

- Pathologist in charge (1 person, 1979 USD)

- Technical (3 people, 990 USD)

- Logistical (4 people, 330 USD)

- Service (2 people, 264 USD)

- Depreciation cost: Dividing the depreciation cost of fix assets by their expected useful life (useful life: 10 to 15 years)

- US Dollar: 30315 Iranian Rials (According to the Central Bank of the Islamic Republic of Iran at the time of the study)

The cost of laboratory services was calculated based on the steps outlined in Fig. 1. In the first stage of this process, using observation and interview, activity centers (the points where works are done) were identified and the followings were considered: laboratory area $\left(\mathrm{m}^{2}\right)$, managerial, technical, and logistical personnel (number of people), depreciation of specialized and other equipment (year), consumable goods (number), energy $\left(\mathrm{m}^{3}\right)$, and quality control (USD).

According to activity centers, cost centers (the points where costs are made) were identified and categorized as direct and indirect costs. The outputs were identified by type of costs. Then, costing was done by analyzing the related (fixed and variable) parameters in the incurred costs. In the next step, to determine the cost price, the cost sharing of each activity center was calculated and determined (18, 19).

In the second phase, the revenue of tests was calculated by the following formula:

Total laboratory revenue $=$ Test tariff $*$ Test frequency

Based on the above formula, all 188 tests that were performed in the laboratory were calculated. These tests were in 12 laboratory groups as follow: Admission and sampling (4 tests), urine analysis (6 tests), clinical chemistry (38 tests), specialized clinical chemistry (21 tests), hormones (32 tests), tumor markers (6 tests), hematology ( 8 tests), coagulation ( 7 tests), blood banks (4 tests), serology and immunology (51 tests), microbiology ( 8 tests), and other tests (3 tests).

After obtaining the costs and revenues of the tests, net profit was calculated using this formula: Net profit $=$ total laboratory revenue - total laboratory cost. Also, with calculating the costing and net profit and implementation of the economic model, sensitivity analysis was done on uncertain

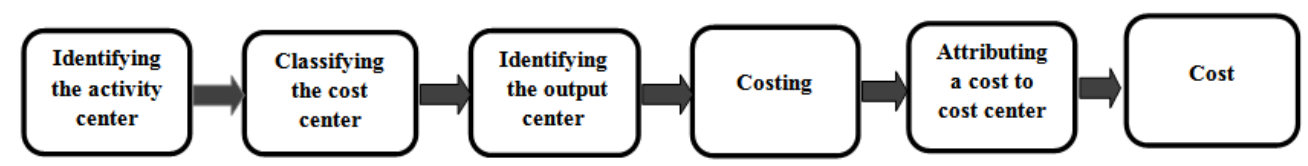

Fig. 1. Cost pricing steps based on activity- based costing (ABC) 
parameters, such as frequency of different tests in the form of $50 \%$ decrease or $50 \%$ increase compared to the existing situation.

\section{Results}

Table 1 presents the cost amount and sharing based on direct and indirect cost centers. Based on this table, direct costs accounted for $78.28 \%$ and indirect costs for $21.72 \%$ of the total costs. In direct cost centers, consumable goods $(47.26 \%)$ were more costly, and in indirect cost centers, the higher cost belonged to rent $(49.55 \%)$.

In the laboratory, the most direct costs were related to hormones tests (120178 USD) and the least costs to other tests (3 248 USD). The highest indirect costs were related to the clinical chemistry tests (38 560 USD) and the least costs to other tests (363 USD). In general, the most cost belonged to consumable goods, with $37 \%$, and the lowest cost to energy, with $0.53 \%$ (Table 2 ).

In addition to calculating the cost of the test groups, the cost of individual test in each group was also calculated and compared with the tariffs. In the coagulation test group, the smallest difference in the cost of tests and tariffs was observed in blood clot test (0.2 USD), and the biggest difference was observed in the anti-platelet antibody test by IVF procedure (36 USD). In the blood bank test group, the smallest difference in the cost of tests and tariffs was detected in indirect coombs test (1 USD), and the biggest difference was seen in direct coombs test (7 USD). In the admission and sampling test group, the smallest difference in the cost of tests and tariffs was detected in virginal, prostate, or urinary tract biopsy (0.5 USD), and the biggest difference was seen in blood sample collection in children under the age of 5 (5 USD).

In the urine analysis test group, the smallest difference in the cost of tests and tariffs was observed in the test of measuring protein in the urine collected during the set time $(0.04$ USD), and the biggest difference was observed in BensJones urine test through a chemical procedure (53 USD). In

Table 1. Cost amount and sharing based on direct and indirect cost centers in the studied Lab - 2015

\begin{tabular}{|c|c|c|c|c|c|c|c|c|c|c|c|}
\hline \multirow[b]{2}{*}{ 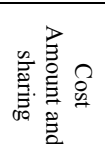 } & \multicolumn{4}{|c|}{ Direct cost centers } & \multirow[t]{2}{*}{ Total } & \multicolumn{5}{|c|}{ Indirect cost centers } & \multirow[t]{2}{*}{ Total } \\
\hline & $\begin{array}{l}\text { Consuma- } \\
\text { ble goods }\end{array}$ & $\begin{array}{c}\text { Depreciation } \\
\text { of specialized } \\
\text { equipment }\end{array}$ & $\begin{array}{l}\text { Professional } \\
\text { human re- } \\
\text { sources }\end{array}$ & $\begin{array}{l}\text { Logistical } \\
\text { human re- } \\
\text { sources }\end{array}$ & & Energy & $\begin{array}{l}\text { Quality } \\
\text { control }\end{array}$ & Rent & $\begin{array}{l}\text { Depreciation } \\
\text { of other } \\
\text { equipment }\end{array}$ & Other & \\
\hline
\end{tabular}

\begin{tabular}{|c|c|c|c|c|c|c|c|c|c|c|c|}
\hline 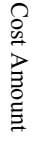 & 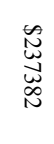 & $\begin{array}{l}\stackrel{\tilde{N}}{心} \\
\text { N }\end{array}$ & $\begin{array}{l}\infty \\
\stackrel{\infty}{0} \\
\stackrel{0}{\circ}\end{array}$ & $\begin{array}{l}\text { N } \\
\text { 岕 } \\
\text { D. }\end{array}$ & 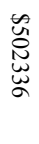 & $\begin{array}{l}\underset{W}{W} \\
\stackrel{D}{D}\end{array}$ & 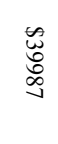 & 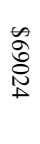 & 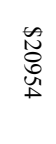 & $\begin{array}{l}\text { 势 } \\
\text { 号 }\end{array}$ & $\begin{array}{l}\omega \\
\omega \\
\omega \\
\omega \\
0 \\
0\end{array}$ \\
\hline 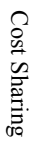 & $\begin{array}{l}\stackrel{\circ}{+} \\
\underset{\sim}{ \pm} \\
\text { N }\end{array}$ & $\stackrel{\circ}{\stackrel{\omega}{0}}$ & $\underset{\stackrel{\infty}{\infty}}{\stackrel{0}{\circlearrowleft}}$ & $\underset{\stackrel{+}{+}}{\stackrel{\circ}{+}}$ & $\begin{array}{l}\stackrel{0}{\infty} \\
\stackrel{\infty}{\infty}\end{array}$ & $\begin{array}{l}\stackrel{\circ}{\circ} \\
\stackrel{+}{+}\end{array}$ & $\begin{array}{l}\stackrel{0}{ \pm} \\
\stackrel{\infty}{0} \\
\dot{0}\end{array}$ & $\begin{array}{l}\stackrel{0}{0} \\
\dot{t} \\
\dot{0} \\
\text { un }\end{array}$ & $\begin{array}{l}\stackrel{\circ}{0} \\
\dot{\phi} \\
\dot{\phi}\end{array}$ & $\frac{0}{\grave{1}}$ & $\stackrel{\stackrel{\sim}{N}}{\stackrel{N}{N}}$ \\
\hline
\end{tabular}

Table 2. Direct and indirect costs based on laboratory tests group - 2015

\begin{tabular}{|c|c|c|c|c|c|c|c|c|c|c|}
\hline \multirow[b]{2}{*}{$\begin{array}{l}\text { Group of laboratory } \\
\text { tests }\end{array}$} & \multicolumn{4}{|c|}{ Direct cost centers } & \multicolumn{5}{|c|}{ Indirect cost centers } & \multirow{2}{*}{$\begin{array}{r}\text { Total } \\
\text { cost } \\
\text { (percent) }\end{array}$} \\
\hline & $\begin{array}{l}\text { Consumable } \\
\text { goods }\end{array}$ & $\begin{array}{c}\text { Depreciation of } \\
\text { specialized equip- } \\
\text { ment }\end{array}$ & $\begin{array}{l}\text { Professional } \\
\text { human re- } \\
\text { sources }\end{array}$ & $\begin{array}{l}\text { Logistical hu- } \\
\text { man resources }\end{array}$ & Energy & $\begin{array}{l}\text { Quality } \\
\text { control }\end{array}$ & Rent & $\begin{array}{l}\text { Depreciation } \\
\text { of Other } \\
\text { Equipment }\end{array}$ & Other & \\
\hline Admission and & $\$ 1006$ & $\$ 000$ & $\$ 4312$ & $\$ 1935$ & $\$ 530$ & $\$ 0$ & $\$ 8700$ & $\$ 3963$ & $\$ 619$ & 3.27 \\
\hline sampling & $0.42 \%$ & $0.00 \%$ & $2.63 \%$ & $2.67 \%$ & $15.62 \%$ & $0.00 \%$ & $12.60 \%$ & $10.58 \%$ & $10.58 \%$ & \\
\hline Urine analysis & $\$ 4415$ & $\$ 0$ & $\$ 5056$ & $\$ 2322$ & $\$ 582$ & $\$ 1601$ & $\$ 9413$ & $\$ 3239$ & $\$ 506$ & 4.23 \\
\hline Urine analysis & $1.86 \%$ & $0.00 \%$ & $3.16 \%$ & $3.20 \%$ & $17.14 \%$ & $4.00 \%$ & $13.64 \%$ & $8.64 \%$ & $8.64 \%$ & \\
\hline Clinical chemistry & $\$ 39308$ & $\$ 23455$ & $\$ 22871$ & $\$ 9508$ & $\$ 1378$ & $\$ 10183$ & $\$ 22299$ & $\$ 1835$ & $\$ 2865$ & 20.84 \\
\hline Specialized clinical & $16.55 \%$ & $72.54 \%$ & $14.29 \%$ & $13.11 \%$ & $40.61 \%$ & $25.47 \%$ & $32.31 \%$ & $48.97 \%$ & $48.97 \%$ & \\
\hline $\begin{array}{l}\text { Specialized clinical } \\
\text { chemistry }\end{array}$ & $\begin{array}{l}\$ 33302 \\
14.03 \%\end{array}$ & $\begin{array}{l}\$ 1445 \\
4.47 \%\end{array}$ & $\begin{array}{l}\$ 23473 \\
14.66 \%\end{array}$ & $\begin{array}{l}\$ 10780 \\
14.86 \%\end{array}$ & $\begin{array}{c}\$ 80 \\
2.36 \%\end{array}$ & $\begin{array}{l}\$ 3981 \\
9.96 \%\end{array}$ & $\begin{array}{l}\$ 1298 \\
1.88 \%\end{array}$ & $\begin{array}{l}\$ 10.68 \\
2.85 \%\end{array}$ & $\begin{array}{l}\$ 167 \\
2.85 \%\end{array}$ & 11.78 \\
\hline Hormones & $\begin{array}{l}\$ 78281 \\
32.98 \%\end{array}$ & $\begin{array}{l}\$ 1672 \\
5.18 \%\end{array}$ & $\begin{array}{l}\$ 27566 \\
17.22 \%\end{array}$ & $\begin{array}{l}\$ 12659 \\
17.45 \%\end{array}$ & $\begin{array}{l}\$ 318 \\
9.38 \%\end{array}$ & $\begin{array}{l}\$ 11745 \\
29.37 \%\end{array}$ & $\begin{array}{l}\$ 10302 \\
14.93 \%\end{array}$ & $\begin{array}{l}\$ 4496 \\
12.00 \%\end{array}$ & $\begin{array}{c}\$ 702 \\
12.00 \%\end{array}$ & 23.03 \\
\hline Tumor markers & $\begin{array}{l}\$ 4411 \\
1.86 \%\end{array}$ & $\begin{array}{l}\$ 186 \\
0.58 \%\end{array}$ & $\begin{array}{l}\$ 5658 \\
3.53 \%\end{array}$ & $\begin{array}{l}\$ 2598 \\
3.58 \%\end{array}$ & $\begin{array}{l}\$ 35 \\
1.05 \%\end{array}$ & $\begin{array}{l}\$ 783 \\
1.96 \%\end{array}$ & $\begin{array}{l}\$ 1148 \\
1.66 \%\end{array}$ & $\begin{array}{l}\$ 501 \\
1.34 \%\end{array}$ & $\begin{array}{c}\$ 78 \\
1.34 \%\end{array}$ & 2.40 \\
\hline Hematology & $\begin{array}{l}\$ 26971 \\
11.36 \%\end{array}$ & $\begin{array}{l}\$ 2705 \\
8.37 \%\end{array}$ & $\begin{array}{l}\$ 7704 \\
4.81 \%\end{array}$ & $\begin{array}{l}\$ 3538 \\
4.88 \%\end{array}$ & $\begin{array}{l}\$ 120 \\
3.54 \%\end{array}$ & $\begin{array}{l}\$ 3250 \\
8.13 \%\end{array}$ & $\begin{array}{l}\$ 3888 \\
5.63 \%\end{array}$ & $\begin{array}{l}\$ 2378 \\
6.35 \%\end{array}$ & $\begin{array}{l}\$ 371 \\
6.35 \%\end{array}$ & 7.94 \\
\hline Coagulation & $\begin{array}{l}\$ 923 \\
0.39 \%\end{array}$ & $\begin{array}{l}\$ 1758 \\
5.44 \%\end{array}$ & $\begin{array}{l}\$ 5176 \\
3.23 \%\end{array}$ & $\begin{array}{l}\$ 2377 \\
3.28 \%\end{array}$ & $\begin{array}{c}\$ 78 \\
2.30 \%\end{array}$ & $\begin{array}{l}\$ 618 \\
1.55 \%\end{array}$ & $\begin{array}{l}\$ 5150 \\
7.64 \%\end{array}$ & $\begin{array}{l}\$ 1545 \\
4.12 \%\end{array}$ & $\begin{array}{l}\$ 241 \\
4.12 \%\end{array}$ & 2.78 \\
\hline Blood Bank & $\begin{array}{l}\$ 525 \\
0.22 \%\end{array}$ & $\begin{array}{c}\$ 80 \\
0.25 \%\end{array}$ & $\begin{array}{l}\$ 5417 \\
3.38 \%\end{array}$ & $\begin{array}{l}\$ 2488 \\
3.43 \%\end{array}$ & $\begin{array}{c}\$ 4 \\
0.10 \%\end{array}$ & $\begin{array}{l}\$ 159 \\
0.40 \%\end{array}$ & $\begin{array}{l}\$ 115 \\
0.17 \%\end{array}$ & $\begin{array}{c}\$ 70 \\
0.19 \%\end{array}$ & $\begin{array}{l}\$ 110 \\
1.88 \%\end{array}$ & 1.40 \\
\hline $\begin{array}{l}\text { Serology and immu- } \\
\text { nology }\end{array}$ & $\begin{array}{l}\$ 27294 \\
11.50 \%\end{array}$ & $\begin{array}{l}\$ 1026 \\
3.18 \%\end{array}$ & $\begin{array}{l}\$ 45020 \\
28.12 \%\end{array}$ & $\begin{array}{l}\$ 20675 \\
28.51 \%\end{array}$ & $\begin{array}{l}\$ 147 \\
4.32 \%\end{array}$ & $\begin{array}{c}\$ 4643 \\
11.61 \%\end{array}$ & $\begin{array}{l}\$ 4742 \\
6.87 \%\end{array}$ & $\begin{array}{l}\$ 1178 \\
3.14 \%\end{array}$ & $\begin{array}{l}\$ 184 \\
3.14 \%\end{array}$ & 16.35 \\
\hline Microbiology & $\begin{array}{l}\$ 20157 \\
8.49 \%\end{array}$ & $\begin{array}{c}0 \$ \\
0.00 \%\end{array}$ & $\begin{array}{l}\$ 6259 \\
3.91 \%\end{array}$ & $\begin{array}{l}\$ 2875 \\
3.96 \%\end{array}$ & $\begin{array}{c}\$ 112 \\
3.30 \%\end{array}$ & $\begin{array}{l}\$ 2884 \\
7.21 \%\end{array}$ & $\begin{array}{l}\$ 1813 \\
2.63 \%\end{array}$ & $\begin{array}{l}\$ 632 \\
1.96 \%\end{array}$ & $\begin{array}{c}\$ 99 \\
1.69 \%\end{array}$ & 5.43 \\
\hline Other & $\begin{array}{l}\$ 789 \\
0.33 \%\end{array}$ & $\begin{array}{c}0 \$ \\
0.00 \%\end{array}$ & $\begin{array}{l}\$ 1685 \\
1.05 \%\end{array}$ & $\begin{array}{l}\$ 774 \\
1.07 \%\end{array}$ & $\begin{array}{c}\$ 10 \\
0.28 \%\end{array}$ & $\begin{array}{l}\$ 140 \\
0.35 \%\end{array}$ & $\begin{array}{l}\$ 156 \\
0.23 \%\end{array}$ & $\begin{array}{c}\$ 49 \\
0.13 \%\end{array}$ & $\begin{array}{c}\$ 8 \\
0.13 \%\end{array}$ & 0.56 \\
\hline SUM & $\begin{array}{c}\$ 237382 \\
37 \%\end{array}$ & $\begin{array}{c}\$ 32327 \\
5.04 \%\end{array}$ & $\begin{array}{c}\$ 160098 \\
24.95 \%\end{array}$ & $\begin{array}{l}\$ 72529 \\
11.30 \%\end{array}$ & $\begin{array}{l}\$ 3394 \\
0.53 \%\end{array}$ & $\begin{array}{c}\$ 39987 \\
6.23 \%\end{array}$ & $\begin{array}{l}\$ 69024 \\
10.76 \%\end{array}$ & $\begin{array}{c}\$ 20954 \\
3.27 \% \\
\end{array}$ & $\begin{array}{l}\$ 5959 \\
0.93 \% \\
\end{array}$ & 100 \\
\hline
\end{tabular}


Table 3. Net profit/ loss of the studied laboratory based on test groups before and after sensitivity analysis - 2015

\begin{tabular}{|c|c|c|c|c|c|c|}
\hline \multirow[t]{2}{*}{ Group of laboratory tests } & \multicolumn{3}{|c|}{ Before sensitivity analysis } & \multicolumn{3}{|c|}{ After sensitivity analysis } \\
\hline & $\begin{array}{l}\text { Total cost } \\
\text { (USD) }\end{array}$ & $\begin{array}{l}\text { Total revenue } \\
\text { (USD) }\end{array}$ & $\begin{array}{c}\text { Net profit / loss } \\
\text { (USD) }\end{array}$ & $\begin{array}{l}\text { Total cost } \\
\text { (USD) }\end{array}$ & $\begin{array}{l}\text { Total revenue } \\
\text { (USD) }\end{array}$ & $\begin{array}{l}\text { Net profit / loss } \\
\text { (USD) }\end{array}$ \\
\hline Admission and sampling & 20966 & 51983 & 31017 & 24700 & 77975 & 53275 \\
\hline Urine analysis & 27134 & 42334 & 15200 & 36711 & 63501 & 26790 \\
\hline Clinical chemistry & 133702 & 406439 & 272737 & 233358 & 609659 & 376301 \\
\hline Specialized clinical chemistry & 75594 & 115029 & 39435 & 111270 & 172543 & 61273 \\
\hline Hormones & 147741 & 382198 & 234457 & 269292 & 573297 & 304006 \\
\hline Tumor markers & 15398 & 84530 & 69132 & 17958 & 126795 & 108837 \\
\hline Hematology & 50925 & 75423 & 24498 & 96238 & 113135 & 16898 \\
\hline Coagulation & 17866 & 66519 & 48653 & 18109 & 99778 & 81669 \\
\hline Blood Bank & 8968 & 2812 & $(6156)$ & 3645 & 4218 & 573 \\
\hline Serology and immunology & 104909 & 129831 & 24922 & 106457 & 194747 & 88290 \\
\hline Microbiology & 34831 & 31250 & $(3581)$ & 66123 & 46875 & (19247) \\
\hline Other & 3611 & 2593 & (1018) & 3211 & 3889 & 678 \\
\hline SUM & 641645 & 1390942 & 749297 & 987071 & 2086413 & 1099342 \\
\hline
\end{tabular}

Table 4. Amount of changes of the laboratory average costs based on test groups before and after sensitivity analysis -2015

\begin{tabular}{lcc}
\hline Group of laboratory tests & Amount of reduced cost (USD) & Net profit / loss (USD) \\
\hline Admission and sampling & $(1)$ & $-\% 36$ \\
Urine analysis & $(9)$ & $-\% 84$ \\
Clinical chemistry & $(2)$ & $-\% 36$ \\
Specialized clinical chemistry & $(3)$ & $-\% 46$ \\
Hormones & $(3)$ & $-\% 57$ \\
Tumor markers & $(1)$ & $-\% 61$ \\
Hematology & $(4)$ & $-\% 32$ \\
Coagulation & $(2)$ & $-\% 30$ \\
Blood Bank & $(7)$ & $-\% 33$ \\
Serology and immunology & $(5)$ & $-\% 47$ \\
Other & $(2)$ & $-\% 73$ \\
\hline
\end{tabular}

the tumor marker test group, the smallest difference in the cost of tests and tariffs was observed in the Alpha-fetoprotein (AFP) test (-6 USD), and the biggest difference was seen in Cirsium antigen 15-3 test (-11 USD).

In the hematology test group, the smallest difference in the cost of tests and tariffs was observed in the Total IgE test (-0.2 USD), and the biggest difference was seen in red blood cell fragility test (60 USD). In the serology and immunology test group, the smallest difference in the cost of tests and tariffs was seen in the coombs wright test $(-0.1$ USD), and the biggest difference was found in Listeria antibody test (IgG, IgM) by ELISA (58 USD). In clinical chemistry test group, the smallest difference in the cost of tests and tariffs was detected in the blood VLDL-C measurement test (0.2 USD), and the biggest difference was seen in the amino acid tests (90 USD).

In the specialized clinical chemistry test group, the smallest difference in the cost of tests and tariffs was found in measuring Vanillyl Mandelic Acid (VMA) test (-1 USD), and the biggest difference was seen in the paper chromatography tests (51 USD). In the microbiology test group, the smallest difference in the cost of tests and tariffs was observed in the direct fungal test (1 USD), and the biggest difference was found in the vaginal culture test (39 USD). And finally, in the hormones test group, the smallest difference in the cost of tests and tariffs was observed in the Aldosterone test (0.2 USD), and the biggest difference was seen in the free beta HCG test (-11 USD).

Also, in the studied laboratory, the net profit was 749297 USD in 2015, with clinical chemistry tests the most profitable (272 737 USD) and urine analysis tests the least profitable tests (15 200 USD). Other tests, microbiology tests, and blood bank accounted for 1018 USD, 3581 USD, and
6156 USD losses, respectively, in the studied laboratory. With an increase of $50 \%$ in uncertain variables, such as frequency of tests in a laboratory, the net profits from 749297 USD per year will increase to 1099342 USD per year (Table 3 ).

As presented in Table 4, with a 50\% increase in uncertain variables, costs of tests reduced from - $\% 30$ in coagulation tests to $-\% 84$ in urine analysis tests. In hormones test group performed in the laboratory, the smallest difference in test's cost and private tariff was observed in ACE test (0.2 USD), and the biggest difference was observed in Calcitonin test (18 USD). In the other test group, the smallest difference in the test's cost and private tariff was observed in measurement of semen fructose (0.4 USD) and the biggest difference was detected in the measurement of the size, count, motility, and morphology of sperm (0.8 USD).

\section{Discussion}

Based on the findings of this study, it was found that direct costs accounted for $78.28 \%$ and indirect costs for $21.72 \%$ of the total costs. The high costs of consumable goods $(47.26 \%)$ and human resources $(46.31 \%)$ increased the direct costs. in the study of Mehrolhassani et al., the share of direct laboratory costs was $94.9 \%$, and compared to the present study, the largest share of these costs was related to human resources (8). Human resources are costly in all parts of a hospital, and this is emphasized by the study of Mouseli et al. that found nurses accounted for 36\% of hospital costs (20). In the studied laboratory, the high cost of consumable goods was justifiable due to the large number of clients and excessive use of these goods. However, the exchange rate fluctuations affected the amount of these costs due to the import of many consumable goods. 
In addition to determining the total share of direct and indirect costs, the share of each of them was also calculated in different test groups. Based on the findings, group tests of hormones $(23.03 \%)$, clinical chemistry $(20.84 \%)$, serology, and immunology $(16.35 \%)$ had the highest cost as well as other tests $(0.56 \%)$, and the blood bank $(1.40 \%)$ had the lowest cost. In the study of Nasiripour, clinical chemistry tests $(52.08 \%)$ had a high share of the cost of tests. In their study, hematological tests $(1.80 \%)$ and microbiology $(3.31 \%)$ had the lowest cost (18). Overall, in laboratories, the cost of different tests depends on the frequency of requests and the cost of a specific test. In the selected laboratory, because it was possible to perform most tests and there were referrals from other laboratories, the frequency of hormones tests was high, and consequently, their costs increased. Also, these tests are inherently costly tests.

Another finding of this study was calculating the cost of individual test in the laboratory tests group and comparing them with the tariff. The biggest cost difference with the tariff in the qualitative measurement of amino acids test was 90 USD per amino acid, and the smallest difference in the measurement of urine in a set duration was 0.04 USD. In the study of Musavi et al., average cost in the laboratory was 0.23 USD, and average variation of the cost was 0.01 USD (13). In the study of Jafari et al., the price of all selected tests was more than tariffs, and the biggest difference was seen in the TSH test (2.80 USD), and the smallest difference was in the ferritin test (0.39 USD). However, vitamin D tests, with the difference of 0.18 USD, and FBS test, with the difference of $0.21 \mathrm{USD}$, were not profitable. In other tests, the price was lower than the tariff (11). Nasiripour et al., in a study, showed that the most share of the cost belonged to urine analysis tests $(21 \%)$ and the least share belonged to biochemistry tests (11\%) (18). Javanbakht et al. also concluded that the cost of services was higher than the state sector tariff (21). In the present study, the tariffs of some tests were low compared to their cost. This can be offset by increasing the frequency of tests; for example, with an increase of $50 \%$ in the frequency of urine analysis test, costs can be reduced from $-30 \%$ to $-84 \%$. Nasiripour et al., in their study, showed that with the increase of test frequency, the difference between calculated cost prices and state sector tariffs were reduced by $-63 \%(18)$.

In general, in this study, total cost, revenue, and net profit in 2015 were 64,645, 1390 942, and 74929 USD, respectively. Clinical chemistry test group with 272737 USD profit had the most share, and urine analysis test group with a 15200 USD profit had the least profit. The other, microbiology, and blood bank tests groups accounted for 1018, 3581 , and 6156 USD in losses, respectively. In a study of Nouri et al., total hospital costs were 8062543 USD (22). Despite the profitability of the studied laboratory, some of the test groups, such as microbiology and blood bank tests, were losses. This requires the adoption of a proper strategy, such as increasing the frequency of these tests by integrating laboratories and establishing mega-labs.

\section{Conclusion}

In this study, the cost and the net profit of the studied la- boratory services and tariffs of laboratories were considered. The studied laboratory was generally profitable, but it was detrimental to some of the test groups, which was due to the high cost of the tests and illogical tariffs. One of the ways to overcome this problem is to increase the laboratory tests. Taking this approach, the laboratories increase their revenue without inflicting additional costs to the patients. Therefore, if the government does not set appropriate policies and regulations, the quality of the non-profitable tests will decrease. The current situation sends a message to laboratory service providers to concentrate more on profitable services. This may affect the quality of laboratory services that are not profitable (orphan tests). Therefore, policymakers should set appropriate rules to ensure the quality of none- profitable tests in the laboratories.

\section{Acknowledgments}

This study was a part of a Ph.D. thesis in health services management at Kerman University of Medical Sciences, Iran. We would like to thank Dr. Mohammad Jafari Sirizi, the director of the Iran Health Insurance Organization and Dr. Zahra Mastaneh, the faculty member of Hormozgan University of Medical Sciences for their assistances in different stages of the study.

\section{Conflict of Interests}

The authors declare that they have no competing interests.

\section{References}

1. Bogdan S, Milena D, Grazyna S. Laboratory medicine as a profession and clinical science -how to perform both of them well? JIFCC. 2010;21(3):1-3.

2. Powell W, Snellman K. The knowledge economy. Annu Rev Sociol. 2004;30:199-220.

3. Bossuyt X, Verweire K, Blanckaert N. Laboratory medicine: challenges and opportunities clinical chemistry. Clin Chem. 2007;53)10(:173033.

4. Asadi F, Moghaddasi H, Mastaneh Z. Situation analysis of Hematology Information Systems in educational therapeutic hospital laboratories of Shaheed Beheshti University of Medical Sciences. HIMJ. 2009;6(1):21. [Persian]

5. Walter H. Henricks, Information system issues facing clinical laboratories serving complex integrated delivery systems. Int J Healthc Manag. 2000:14(3):55-67.

6. Mouseli A, Barouni M, Amiresmaili MR, Mirab Samiee S, Vali L. Costprice estimation of clinical laboratory services based on activitybased costing: A case study from a developing country. Electron Physician. 2017;9(4):4077-83.

7. Yusefzadeh H, Ghaderi H, Bagherzade R, Barouni M. The efficiency and budgeting of public hospitals: case study of Iran. Iran Red Crescent Med J. 2013;15(5):393-99.

8. Mehrolhassani MH, Heidari MR, Rahimi Z, Emami M. Cost price estimation of clinical laboratory services in Shafa Hospital based on Activity-based Costing, Kerman, 2011. Quarterly J Sabzevar Univ Med Sci. 2014;21(4):587-95.

9. Hafezi R, Abolhallaje M, Ramezanian M. Designing new financial management system in health sector of Islamic Republic of Iran. Iran J Public Health. 2009;38(1):173-8.

10. Saber-Mahani A, Goodarzi G, Barouni M, Khakian M. Estimation of technical efficiency of general hospitals of Kerman University of Medical Sciences by data envelopment analysis (DEA) method in 2007. J Kerman Univ Med Sci. 2010;17(1): 59-67.

11. Jafari Sirizi M, Barouni M, Saber Mahani A. Analysis of cost price and net profit of paraclinic services in private and public sectors: a case study of Kerman city 2014. J Health Man \& Info. 2015;2(4):13843 
12. Talaee Zavareh SH. A study on the establishment of performancebased budgeting using the $\mathrm{ABC}$ technique in the organization of educational research and planning (OERP) of the Ministry of Education. J Educational Innovations. 2011;9(36): 150-72.

13. Mousavi SA, Khorvash F, Fathi H, Fadai H, Hadianzarkeshmoghadam S. Survey the average of cost in outpatient and imaging in Alzahra Hospital and comparing with service's tariff. HIMJ. 2010;7(2):23542.

14. Charuruks N, Chamnanpai S, Seublinvog T. Cost analysis of laboratory tests: a study of the central laboratory of King Chulalongkorn Memorial Hospital. J Med Assoc Thai. 2004; 87:955-63.

15. Farris PW, Bendle NT, Pfeifer PE, Reibstein DJ. Marketing metrics: the definitive guide to measuring marketing performance. 2nd Edi. USA: Pearson Education, 2010.

16. Buljanovic V, Patajac H, Petrovecki M. Clinical laboratory as an economic model for business performance analysis. Croat Med J. 2011;52:513-19.

17. Mouseli A. Designing regional integrated laboratory services delivery network in Kerman province. Thesis of PhD degree, Kerman University of Medical Sciences, 2017. [Persian]

18. Nasiripoor A, Tabibi J, Maleki M, Nourozi T. Computation cost price of clinical laboratories services in Valiasr hospital in Tehran in 1387 by using of ABC model. J hosp. 2010;8(3 and 4):5-17.

19. Goeree MR, Gafni A, Hannah M, Myhr T, Blackhouse G. Hospital selection for unit cost estimates in multicenter economic evaluations. Pharmacoeconomics. 1999;15(6):561-72.

20. Mouseli A, Mehrolhasani MH, Mastaneh Z, Vali L. Quantitative optimization of nurses in emergency department of teaching hospital: a case study. Proceedings of the International Conference on Industrial Engineering and Operations Management, Kuala Lumpur, Malaysia, March 8-10, 2016.

21. Javanbakht M, Mashayekhi A. Salavati S, Mohammadzadeh A. Application and designing Activity Based Costing system in radiology ward of Hafez hospital 2009. J Med Council of IRI. 2013;31(1):1523.

22. Nouri M, Markazi Moghaddam N, Goudarzi R, Meshkani Z. A survey on Activity Based Costing in final units: case study of armed hospital. J Hosp. 2016;15(1):41-50 